\title{
INTEREST LIMITATION RULE UNDER ATAD: Case of The Czech Republic
}

\author{
Aneta Pivoňková ${ }^{1}$, Jana Tepperová $^{2}$
}

\begin{abstract}
The anti-tax avoidance directive (ATAD) implemented in the EU countries in 2019 has brought, among other things, a common rule for tax-deductibility of exceeding borrowing costs of corporate taxpayers - the interest limitation rule. For interest limitation, the Czech Republic had so far used the so-called safe haven thin capitalisation rule. With the implementation of ATAD, companies need to test not only the thin capitalisation rule but also the new interest limitation rule according to ATAD. This paper aims to review the impact of the new interest limitation rule on the 200 largest Czech companies by their 2017 revenue as recorded in the Albertina database. Results covering the new rules, i.e. following the ATAD implementation, are being compared to the situation before the implementation. Most of the analysed companies seem unaffected by the new interest limitation rule. The analysis also showed that most of the analysed companies do not imply exceeding borrowing costs, either before or following the ATAD implementation.
\end{abstract}

\section{Keywords}

ATAD, BEPS, Thin Capitalisation Rule, Interest Limitation Rule

\section{Introduction}

Multinational enterprises (MNEs) optimise their worldwide tax liability by the means of using different effective tax rates and other country-specific differences in the tax systems through shifting taxable profits and building a significant part of the tax gap in both the OECD and EU countries (e.g. Murphy, 2019; Tørsløv et al., 2018; International Monetary Fund, 2015). There are different strategies of MNEs for shifting taxable profits, typically involving e.g. transfer mispricing (e.g. Davies et al., 2015; Vicard, 2015), royalties (e.g. Evers and Spengel, 2014; Fuest et al., 2013), exceeding borrowing costs (e.g. Janský and Kokeš, 2015, 2016), or others.

\footnotetext{
${ }^{1}$ University of Economics, Prague, W. Churchill Sq. 4, 13067 Prague 3, Czech Republic. E-mail: anetapivonkova@seznam.cz.

${ }^{2}$ University of Economics, Prague, W. Churchill Sq. 4, 13067 Prague 3, Czech Republic.

E-mail: jana.tepperova@vse.cz.
} 
The European Commission (2017) has identified 7 models of aggressive tax planning and specified 33 indicators of tax systems that either promote or allow the aggressive tax planning behaviour. No thin capitalisation rule and no interest limitation rule are included among these indicators, specified in 4 of the seven models, specifically within the structures that adopt offshore loan, hybrid loan, hybrid entity and interest-free loan. There has been a strong reaction to aggressive tax planning, first represented mainly by the OECD project Base Erosion and Profit Shifting (BEPS) with its output of 15 final reports containing recommendations for different tax measures aimed at eliminating or reducing the undesired tax avoidance. One of those recommendations is the common interest limitation rule of up to $10-30 \%$ of EBITDA, e.g. earnings before interest, tax, depreciation and amortization (OECD, 2016). Consequences of the implementation of the Action 4 of BEPS are discussed, for example, by Burnett (2019). Some countries take their own action on interest limitation. Harju et al. (2017) study the changes in the behaviour of Finnish, Swedish and Danish MNEs following the introduction of new interest barriers in Finland. They report a decrease in the Finnish financial expenses and the long-term debt levels of subsidiaries. Other empirical evidence shows that thin capitalisation rules have a limiting effect on the debt financing intended to base erosion (de Mooij and Liu, 2021, Overesch, 2009, Blouin et al., 2014).

Inspired by BEPS reports, the European Commission adopted the Anti-Tax Avoidance Directive (ATAD), which requires all the EU member states to implement 5 tax measures, including the interest limitation rule. The rule under ATAD limits interests by the amount of $30 \%$ of EBITDA or by EUR 3 bn., whichever is higher.

Until the implementation of ATAD, interests for the Czech residential companies have been limited by the thin capitalisation rule, which applies only to related entities. The thin capitalisation rule for related entities remains applicable also following the implementation of ATAD; the new rule of $30 \%$ of EBITDA (or up to CZK $80 \mathrm{bn}$., settled as an equivalent of EUR 3 bn.) will be applicable alongside. Contrary to the thin capitalisation rule, the new interest limitation rule is applicable in general, i.e. not limited to only related entities. This paper aims to survey to what extend the Czech companies will be affected by the new interest limitation rule and to compare exceeding borrowing costs (tax non-deductible interests) before and after the implementation of ATAD in the Czech Republic. Calculations are based on the data for the 200 largest Czech companies by their 2017 revenue, derived from the Albertina database.

This paper builds on the diploma thesis (Pivoňková, 2019), successfully defended at the Prague University of Economics and Business.

\section{Thin Capitalisation Rules in the EU Countries}

In most of the EU countries, the deductibility of borrowing costs for tax purposes has been limited already before the implementation of ATAD. There were two major approaches to the thin capitalization rule: the safe haven rule and the earnings stripping rule (Mardan, 2015). The safe haven rule limits the tax-deductibility of interest payments to related parties up to a certain debt-to-equity ratio. The earnings stripping rule derives the taxdeductibility of interest payments from the fraction of the corporate EBITDA. 
In the case of the absence of specific thin capitalization rules, countries have resorted to the so-called subjective approach, meaning that only general principles for tax-deductibility, such as the arm's length principle, got applied (Dukic, 2011).

Since interest deductions were used as a powerful tool within aggressive tax planning, following the post-2000 heated debates on countering aggressive tax planning behaviour the individual countries often either modified or adopted new thin capitalization rules.

According to Dukic (2011), 7 EU countries did not have by 2011 any specific thin capitalization rules and adopted only the subjective approach. These countries were Cyprus, Estonia, Finland, Malta, Slovakia, Sweden and the United Kingdom. Three other EU member states (Austria, Ireland and Luxemburg) limited interest payments by other modes of restrictions, implied mainly from the administrative practice. Based on the survey by the European Commission (2015), only four member states (Cyprus, Estonia, Ireland and Malta) did not have any thin capitalization rules.

The earnings stripping rule was long-term used only in Germany and Italy. Most of the EU countries have adopted the fixed debt-to-equity ratio. The debt-to-equity ratio differs among the member states and underwent some changes as well. Belgium serves as an example of extreme ratios of 1:1 and 7:1 for different situations before 2012, moving to the 5:1 ratio following 2012 and as of 2020, under ATAD, switching to the earnings stripping rule based on the corporate EBITDA while keeping the 5:1 thin capitalization rule only for interests to tax havens (PWC, 2021; DLA Piper, 2012). However, most of the EU countries kept the debt-to-equity ratio at either 3:1 or 4:1 (Dukic, 2011).

With the implementation of ATAD, as of January 2019 the EU countries have been required to implement the interest limitation rule based on the corporate EBITDA, in its own way a kind of the earnings stripping rule,. At the same time, the countries are free to keep another thin capitalization rule alongside. According to the report by the European Commission (2020), most of the countries have already implemented the new interest limitation rules as required, while 4 countries (Austria, Denmark, Ireland and Spain) were in the middle of infringement procedures (as of the date of the report's publishing).

\section{Tax Deductibility of Borrowing Costs in the Czech Republic}

According to the Income Tax Act No. 586/1992 Coll. (hereinafter referred to as "ITA"), borrowing costs can be considered tax-deductible if related to achieving, securing and maintaining taxable income. However, tax-deductibility of borrowing costs is further limited by mainly three rules - the thin capitalisation rule (Section 25 (1) w of ITA), limitation of the parents' financial costs (Section 25 (1) zk) of ITA) and costs mainly dependent on the debtors' profits (Section 25 (1) zl) of ITA). In certain forms, thin capitalisation rules were common to the Czech income tax law since the adoption of the Constitution of the Czech Republic in 1993. However, until the 2009 general revisions both to this rule and to the definition of related parties, its application was ambiguous (Sobotková, 2010). We further focus on the thin capitalisation rule in the form of the safe haven rule compared to the new interest limitation rule according to ATAD, i.e. the earnings stripping rule. Both these rules are currently applied along with each other. 


\section{Safe haven thin capitalisation rule}

In general, financial costs are considered to be tax-deductible expenses. On the other hand, profit-sharing is usually tax non-deductible expense. For that reason, companies are motivated to finance their investment by loans rather than by investing in the company's capital, meaning debt financing might be favoured to equity financing. By using taxdeductible interests, companies can optimize their tax liability by shifting borrowing costs to a high-tax jurisdiction, thus lowering the taxable profit there. The thin capitalisation rule, stated in Section 25 (1) w) of ITA, aims to limit the tax-deductibility of interests related to debt financing among related entities and preferred to equity financing, the so-called exceeding financial costs. This is common practice for many countries (Pekárek and Pilařová, 2016).

According to the thin capitalisation rule as specified by ITA, tax non-deductible is considered the part of the financial costs by which the total amount of credit financial instruments from related entities exceeds six times the shareholders' equity during the tax period (in case the recipient of the given credit instrument is a bank or insurance company), or four times the equity (for other, non-financial recipients).

Since the thin capitalisation rule applies only to so-called related entities, it is crucial to specify when the companies are considered to be related. Companies are, according to Section 23 (7) of ITA, considered to be related either by capital (capital-related), or otherwise.

A capital-related entity is an entity that directly or indirectly participates in the capital or voting rights of at least one other entity, and the share of this participation represents at least $25 \%$ of the registered capital or $25 \%$ of the voting rights. Related otherwise are entities where one person participates in the management or control of another person, or the same person (or the so-called close person, respectively) participates in the management or control of other persons. ITA considers as otherwise related also controlling and controlled entities or entities controlled by the same controlling entity, or entities that have been established primarily to reduce the tax base or increase tax loss. There are also exceptions, e.g. the situation when one person is a member of the supervisory board of two entities. In addition, ITA does not consider participation in a control commission or similar control body or performing control for remuneration as a contribution to the control. The share of the capital or voting rights in the tax period (or in the period for which the tax return is filed) is determined as an arithmetic average of the monthly held company stock.

Calculation of the thin capitalisation rule is specified within the Instruction of General Financial Directorate No. D-22 (further referred to as "Instruction D-22"). Pursuant to the Instruction D-22, the amount of tax non-deductible financial costs shall be determined for a debtor, who is not a bank or insurance company, as follows:

1. The first step is to calculate the ratio based on the following formula:

$$
\frac{4(\text { or } 6) \times S O E}{Y}<1
$$


where $S O E$ is the state of equity as of the first day of the relevant tax period if there is no change in equity during this period. If there is a change in equity during this period, the average equity balance, calculated as the average of equity stocks, is decisive; the change in equity as a result of the reported equity is not taken into consideration. $Y$ is the average of the daily stocks of credit financial instruments from related entities, excluding credit financial instruments interest of which is included in the cost of assets and interest-free credit financial instruments.

2. If the ratio is less than 1 , the coefficient $K$ shall be calculated:

$$
K=1-\frac{4(\text { resp. 6) } \times S O E}{Y}
$$

3. The amount of tax non-deductible interests shall be calculated according to the following formula:

$$
\text { Tax non_deductible interests }=v+t+(K \times u)
$$

where $v$ represents financial costs to related entities excluded in $100 \%$ according to Section 25 (1) zl) of ITA, $t$ stands for financial costs to unrelated entities excluded in $100 \%$ according to Section 25 (1) zl) of ITA, and $u$ represents other financial costs from credit-related financial instruments from related entities (the total financial costs of the credit financial instruments from related entities after deducting the financial expenses $v$ ).

If the company reports negative equity, then all financial costs arising from the received credit financial instruments pursuant to Section 25 (1) w) of ITA are considered as tax non-deductible.

According to the Czech Accounting Standard for Entrepreneurs No. 018 Capital Accounts and Long-term Liabilities, the amount of equity includes the following accounts:

* 41 - Registered capital and capital funds,

* 42 - Reserve funds, indivisible fund and other funds from profit and transferred economic results,

* 43 - Profit or loss.

Pilařová (2012) points out that it is necessary to analyse the changes that may cause fluctuations in equity during the calculation of exceeding financial costs. These changes include, for example, increases in the registered capital by means of shareholder contributions, valuation differences in company transformations, valuation differences from equity interests, share premia in addition to the registered capital, etc.

As to the Instruction D-22, a weighted arithmetic average is recommended to determine the equity. However, since the Instruction D-22 is merely a methodological aid and not legally binding, the use of a simple arithmetic average is not explicitly prohibited by ITA. Thus, if the taxpayer considers it appropriate, a simple arithmetic average instead of the weighted one may be used (Sobotková, 2012). 
The " 4 to 1 " ratio of the thin capitalisation test is rather advantageous for the Czech companies compared to other countries. For example, in France it is "1.5 to 1" (Deloitte, 2018 b), or in Poland " 1 to 1 " (Deloitte, 2017). The same ratio "4 to 1 " is for example in Denmark (Deloitte, 2018a).

\section{Earnings stripping interest limitation rule based on ATAD}

Effective since April 1, 2019, changes related to ATAD has been implemented into ITA. Limitation of exceeding borrowing costs has been newly regulated by Section $23 \mathrm{e}$ of ITA. ITA defines, in Section 23e (1), the basic rule for limiting the exceeding borrowing costs as borrowing costs exceeding the greater of following two values: a) $30 \%$ of the corporate EBITDA, or b) CZK 80 bn.

The taxpayer, i.e. the corporation, will determine the tax non-deductible exceeding borrowing costs under the new rule as follows:

1. Firstly, the corporation calculates the amount of exceeding borrowing costs, defined according to ITA as “. . . borrowing costs, which are the costs incurred in obtaining, securing and maintaining taxable income after deducting taxable borrowing income for the tax year or the period for which the tax return is submitted" (Section 23e (2) of ITA). Borrowing costs are further specified in Section 23e (3) of ITA.

2. If the amount of exceeding borrowing costs does not exceed CZK 80 bn. or $30 \%$ of the corporate EBITDA, all the borrowing costs will be considered as tax-deductible.

3. If the amount of excessive borrowing costs exceeds CZK 80 bn. or $30 \%$ of the corporate EBITDA, whichever of the two is greater, then the excess amount will be considered as tax non-deductible costs. ITA provides the possibility to deduct these tax non-deductible exceeding borrowing costs from the tax base over the future tax periods.

As the thin capitalisation rule operates along the new interest limitation rule, the taxpayer first applies the thin capitalisation rule and then the new interest limitation rule according to ATAD. Both limits need to be respected.

The main differences between the thin capitalisation rule and the interest limitation rule according to ATAD are as follows:

1. The ATAD rule will apply to borrowing costs both from related and unrelated entities (i.e. including, for example, bank loans).

2. The definition of borrowing costs is broader under the interest limitation rule according to ATAD than the definition of the financial costs for the purposes of the thin capitalisation rules (as opposed to thin capitalisation, these also include interest capitalized on the cost of assets, interest on lease payments, or foreign exchange rate differences related to financing). 


\section{Data and Methodology}

We adopt a comparative analysis of exceeding borrowing costs before and following the implementation of ATAD.

Data characteristics:

* We work with a sample of 200 largest companies in the Czech Republic (as of 2017).

* The companies were selected based on their revenue.

* The list of companies was generated from the Albertina database.

* Financial statements and annexes to financial statements are used for additional information.

* The 200 companies were classified into 12 groups according to the industry type; one group was recorded as "other" for the 18 companies that were within the whole sample industry-singular. Most companies were from the automotive industry (54), trade (30) and mining and power-generating industry (27).

* Seven companies were excluded from further analysis; to some the new rules do not apply to and some have not provided by the time of our analysis the necessary public documents.

* Excessive borrowing costs are calculated as borrowing costs minus borrowing income; therefore when borrowing income exceeds borrowing costs, excessive borrowing costs get negative.

We are aware of the limitations caused by the necessary simplifications which may create differences vis-à-vis the real tax non-deductible costs of the analysed companies.

Firstly, only publicly available data were used. There may exist specific, publicly unavailable facts with the potential to affect the performed calculations.

We do not include tax non-deductible interest according to Section 25 (1) zk) and zl) of ITA. Information necessary for such calculations were not available for any of the analysed corporate subjects.

For the calculation of tax non-deductible interests under the thin capitalisation rule, we use only the closing balance of the loan to related entities on the last day of the taxation period. In practice, the average daily balance of the loan would be calculated based on the changes during the taxation period. This information is not mandatorily published and thus it was not possible to include into our calculations the changes during the taxation period.

The EBITDA figures were determined using the accounting data, i.e. based on accounting profit, taxation, depreciation and interest. This simplification is due to the impossibility to identify tax EBITDA from the publicly available data. In practice, companies should calculate EBITDA based on the information from the tax return (row 220 of the tax return), plus tax depreciation, excessive borrowing costs, and the positive valuation difference when purchasing a business plant.

Having necessary simplifications and assumptions in mind, we provide a comparison of the tax non-deductible exceeding borrowing costs before and after the implementation of ATAD into the Czech legislation, using a larger sample of the companies in the Czech Republic. 


\section{Results}

First, we present the results before the implementation of ATAD, thus considering only the thin capitalisation rule. Next, we follow with the results reflecting the situation after the implementation of ATAD. In both cases, we also provide distinctions as to the industry sectors.

\section{Situation before the implementation of ATAD}

Before the implementation of ATAD, there has been used only the thin capitalisation rule. Figure 1 provides an overview of the results for our sample. Only 3 of the 200 analysed companies incurred tax non-deductible interests due to the thin capitalisation rule. In the case of two companies of the above-mentioned three subjects (namely, Grammer CZ, s.r.o. and Yanfeng Czechia Automotive Interior Systems, s.r.o.), considered as tax nondeductible are all the interests since these particular companies have negative equity. One company (Spolana a.s.) incurred only partially tax non-deductible financial costs from related entities. For this company, the share of four times its equity to the value of loans and borrowings from related entities was less than 1 , and therefore the company will have to report part of the interest as tax non-deductible.

The calculation shows that most of the companies from our sample either do not record loans from related entities at all (49.50\% of the companies), or do have loans, but the share of four times their equity to the value of these loans is higher than 1 and therefore no tax non-deductible costs due to the thin capitalisation rule (47.50\% of companies) apply.

Figure 1: Application of the thin capitalisation rule on the sample of 200 largest companies in the Czech Republic, based on the 2017 data

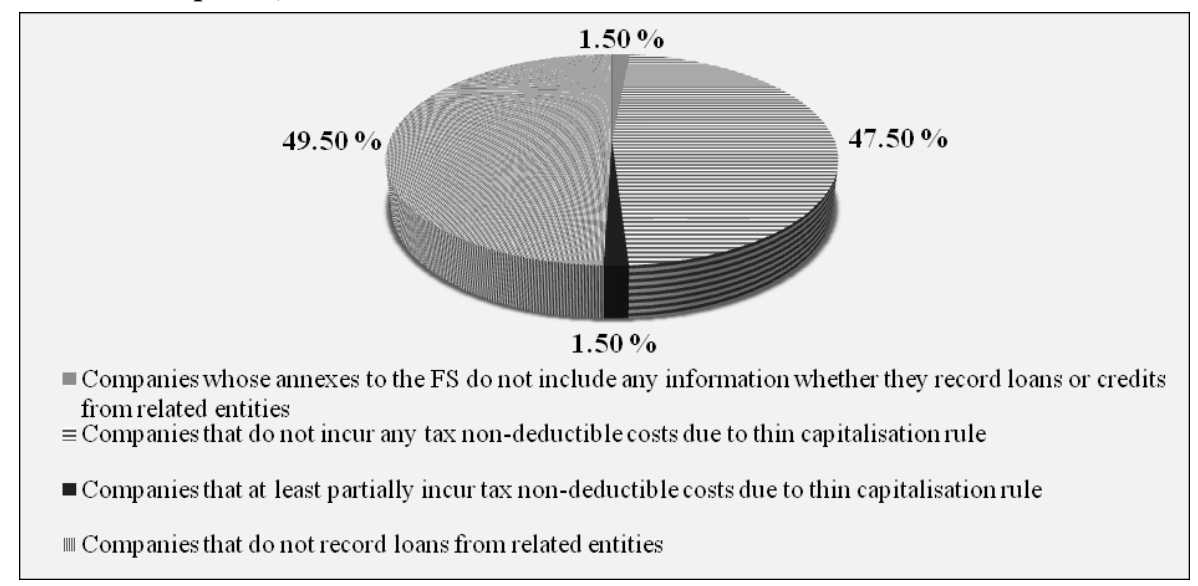

Source: Financial statements and annexes to financial statements of the companies for 2017, own calculation

In Figure 2, we split the companies into individual economic sectors. The largest companies in the Czech Republic are mainly in the automotive, mining and energy sectors, and also in the trade in food, beverages, etc. For the main sectors of the economy, about $50 \%$ of 
the companies do not record loans and about $50 \%$ of the companies register loans but do not incur tax non-deductible costs. Two companies (of the total of five) in the plastics sector register tax non-deductible costs due to the thin capitalisation rule. This finding is interesting when compared to the other sectors. For further research it could be valuable to focus on the plastic manufacturing companies and to find out, if they are more likely to have the ratio of less than 1 or whether this research result is merely due to some other random events, relevant to the two particular companies and not to the field as a whole.

Figure 2: Application of the thin capitalisation rule on the 200 largest companies, economic sectors' overview and the number of companies

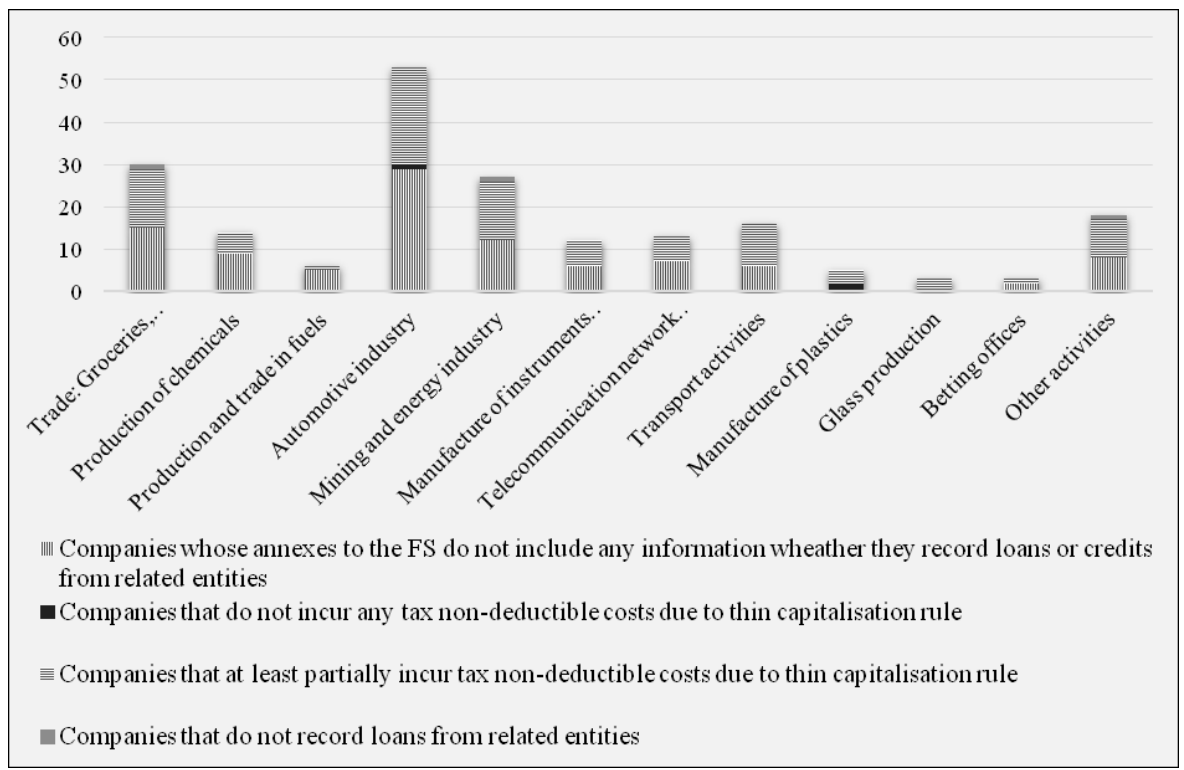

Source: Financial statements and annexes to financial statements of the companies for 2017, own calculation

Our analysis shows that the thin capitalisation rule affects only a very small number of companies in the respective sample. Most companies did not record loans from related entities at all, or their equity capital was so high that no tax non-deductible interest was generated.

\section{Situation following the implementation of ATAD}

Following the implementation of ATAD, along the thin capitalisation rule there gets applied also the new interest limitation rule. In Figure 3 we provide an overview of the calculations of excessive borrowing costs on the sample of 200 largest companies in the Czech Republic, based on the 2017 data. The results indicate that 17 of the 200 analysed companies have exceeded the limit of CZK $80 \mathrm{bn}$. and we must therefore proceed with the calculation of EBITDA. The rest of the analysed companies have all their borrowing costs classified as tax-deductible since their value was below the threshold limit of CZK 80 bn. 
Figure 3: Application of the new interest limitation rule following the implementation of ATAD on the sample of 200 largest companies in the Czech Republic, based on the 2017 data

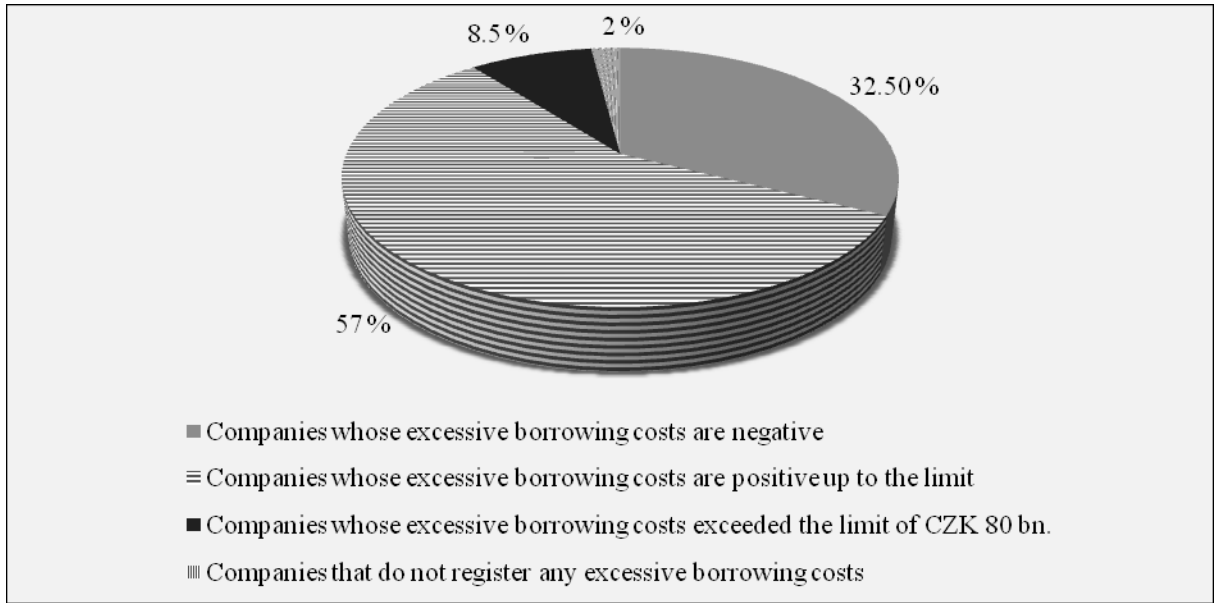

Source: Financial statements and annexes to financial statements of the companies for 2017, own calculation

Figure 4: Application of the new interest limitation rule following the implementation of ATAD on the 200 largest companies, economic sectors' overview and the number of companies

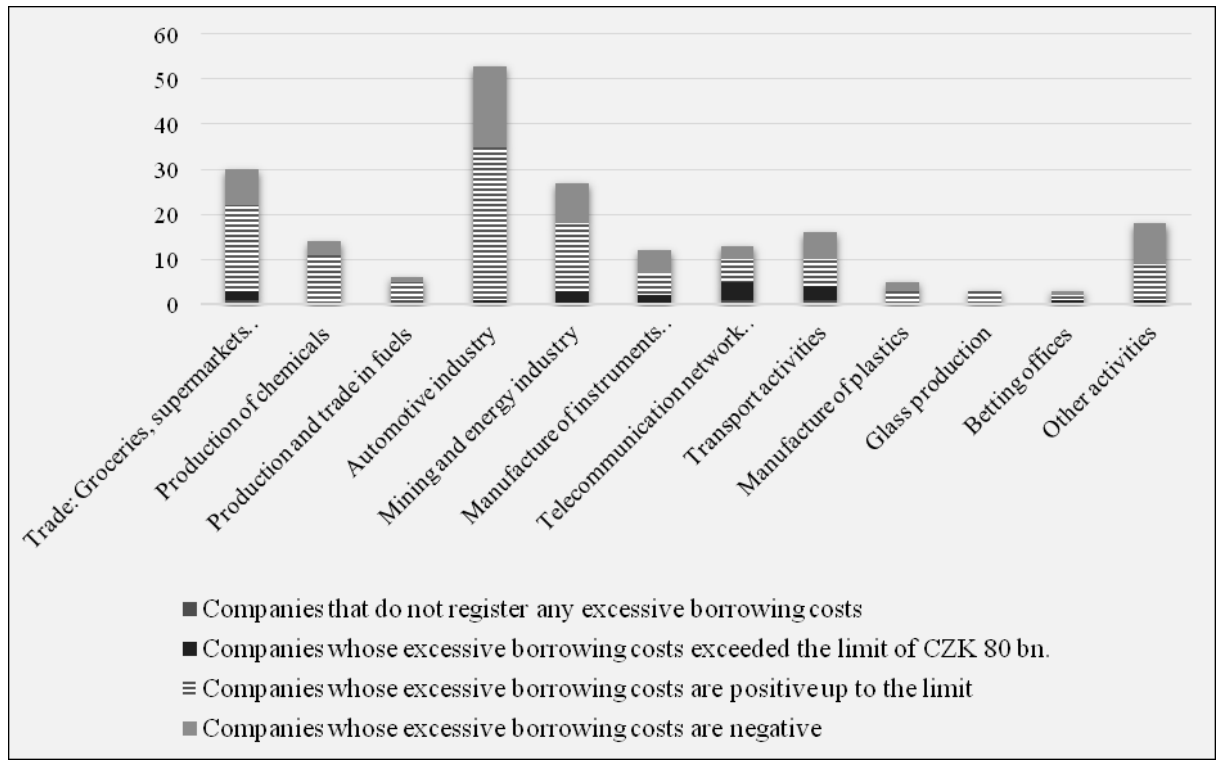

Source: Financial statements and annexes to financial statements of the companies for 2017, own calculation 
In Figure 4, we provide an overview of the results split into individual sectors of the economy. The threshold of CZK 80 bn. was exceeded mainly by the companies operating in the fields of telecommunications services and transport. Several companies were also active in the mining and energy industries and in the sector of food, beverage and similar. Interestingly, only 1 company of the total of 53 automotive companies exceeded the limit of CZK 80 bn. This is also because many of these companies realized higher borrowing revenues than borrowing expenses. Several companies have also reported negative excessive borrowing costs, mainly those active in the extractive and energy industries, food and beverage, and other activities.

The analysis shows that only a very small number of the companies in our sample was affected by the new interest limitation rule adopted following the implementation of ATAD.

\section{Conclusion}

The paper aimed to analyse the impact of the new interest limitation rule implemented under ATAD in the Czech legislation as of April 1, 2019. Implementation of the new interest limitation rule was demonstrated using the sample of 200 largest companies in the Czech Republic, based on the 2017 data collected from the Albertina database and financial statements of the respective companies. Calculations were founded on the publicly available data only and thus do not reflect the real tax non-deductible costs of the companies involved.

Based on the analysis, it was found that only three companies of the total of 200 have incurred tax non-deductible financial costs before the implementation of ATAD. This is due to the ratio of equity to loan (four to one). If this ratio was to be lowered, other companies would be affected as well. For example, provided this ratio was settled to "one to one", eight other companies from our sample would be affected by the thin capitalisation rule and would generate the corresponding tax non-deductible costs.

Following the implementation of ATAD, the thin capitalisation rule is still applicable and complemented by the new interest limitation rule. Excessive borrowing costs are newly limited to $30 \%$ of EBITDA or CZK $80 \mathrm{bn}$. After applying the new interest limitation rule on our sample of 200 companies, we conclude that even though 17 of the 200 companies exceeded the limit of CZK 80 bn., only one company exceeded 30\% of EBITDA. Thus only a small fraction of the companies in our sample was affected by the implementation of the new interest limitation rule under ATAD. This is mainly due to the high value of EBITDA for most of the analysed companies. However, it should be noted that the research was based on the value of the accounting EBITDA instead of the tax values. In practice, analysed companies might incur tax non-deductible excessive borrowing costs because of the lower tax when compared to the accounting EBITDA. These calculations would require other than publicly available data.

The safe haven rule with the fixed debt-to-equity ratio and the earnings stripping rule linked to EBITDA are two most common rules adopted in practice to limit the interest deduction. Mardan (2015) has researched which variant should be used in practice to maximise the welfare of the given country. The different impact of the respective rules is given by their 
nature, since the safe haven rule limits the volume of internal debt, whereas the earnings stripping rule focuses on the limitation of interest payments. The author concludes that the earnings stripping rule can be beneficial for financially advanced countries, as it favours financially strong corporations relatively more than the safe haven rule. Therefore, according to Mardan, this explains why most countries opted to implement the safe haven rule and later those which were more financially advanced often switched to the earnings stripping rule. As of now, when all the EU member states use the earnings stripping rule based on ATAD, the question arises whether this is beneficial for the countries to keep the safe haven rule along, or rather to abolish it to maximise its welfare.

MNEs use various techniques for base erosion and profit shifting and debt financing is only one of them. As demonstrated by our sample, low impact of the interest limitation rules both before and following the ATAD implementation could mean that the analysed companies have already adapted to the safe haven rule with internal debt financing and make use of other techniques to optimise their tax liability (if doing so). The newly introduced earnings stripping rule would not possibly affect them for the same reason, considering the high values of corporate EBITDA within our sample.

Even before the implementation of ATAD, the Czech Republic has already limited taxdeductibility of interest to related entities by the thin capitalisation rule. Other measures from ATAD, such as CFC rules, hybrid mismatches and exit tax, are completely new to the Czech tax system.

\section{Acknowledgements}

The paper was prepared as one of the outputs of a research project of the Faculty of Finance and Accounting at the University of Economics "Economic and institutional aspects of public finance" registered by the Internal Grant Agency of University of Economics, Prague under the registration number F1/7/2019; and as an output of a research project "Fair corporate taxation: Measurement of the impact of the corporate profit shifting on the budget of the Czech Republic" registered by the Czech Science Foundation under the registration number 18-14082S.

\section{References}

Blouin, J., Huizinga, H., Leaven, L. and Nicodeme, G. J. A. (2014). Thin Capitalization Rules and Multinational Firm Capital Structure. CESifo Working Paper Series 4695, CESifo Group Munich.

Burnett, C. (2019). Interest Deductibility: Implementation of BEPS Action 4 and the Future of Transfer Pricing of Intragroup Finance (September 25, 2019). Bulletin for International Taxation, 73(6/7), pp. 325-331. Sydney Law School Research Paper No. 9/59. Available at SSRN: https://ssrn.com/abstract=3459350.

Davies, R., Martin, J., Parenti, M. and Toubal, F. (2015). Knocking on Tax Haven's Door: Multinational Firms and Transfer Pricing. SSRN Paper No. ID2666947.

de Mooij, R. and Liu, L. (2021). At a Cost: The Real Effects of Thin Capitalization Rules. WP/21/23. International Monetary Fund. 
Deloitte (2017). Taxation and Investment in Poland 2017 [online]. Retrieved January 03, 2020, from https://www2.deloitte.com/content/dam/Deloitte/global/Documents/Tax/dttltax-polandguide-2017.pdf.

Deloitte (2018a). International Tax Denmark Highlights 2018 [online]. Retrieved January 03, 2020, from https://www2.deloitte.com/content/dam/Deloitte/global/Documents/Tax/ dttl-tax-denmarkhighlights-2019.pdf.

Deloitte (2018b). International Tax France Highlights 2018 [online]. Retrieved January 03, 2020, from https://www2.deloitte.com/content/dam/Deloitte/global/Documents/Tax/dttltax-francehighlights-2019.pdf.

Dukic, T. (2011). Thin Capitalization Rules in EU Member States. Uprava, IX(2), 83-99. European Commission (2015). Study on Structures of Aggressive Tax Planning and Indicators. Final Report. WP no. 61.

European Commission (2017). Aggressive tax planning indicators. Final Report. WP No. 71.

European Commission (2020). Report from the Commission to the European Parliament and the Council on the implementation of Council Directive (EU) 2016/1164 of 12 July 2016 laying down rules against tax avoidance practices that directly affect the functioning of the internal market as amended by Council Directive (EU) 2017/952 of 29 May 2017 amending Directive (EU) 2016/1164 as regards hybrid mismatches with third countries. $\operatorname{COM}(2020) 383$ final.

European Union (2016). Council Directive (EU) 2016/1164 of 12 July 2016 laying down rules against tax avoidance practices that directly affect the functioning of the internal market.

Evers, L. and Spengel, C. (2014). Effective Tax Rates Under IP Tax Planning. ZEW Centre for European Economic Research Discussion Paper No. 14-111. Available at SSRN: https://ssrn.com/abstract=2555488 or http://dx.doi.org/10.2139/ssrn.2555488.

Fuest, C., Spengel, C., Finke, K., Heckemeyer, J. and Nusser, H. (2013). Profit Shifting and 'Aggressive' Tax Planning by Multinational Firms: Issues and Options for Reform. SSRN Electronic Journal. Available at SSRN: https://ssrn.com/abstract=2343124 or http://dx. doi.org/10.2139/ssrn.2343124.

DLA Piper (2012). Global Tax News: Belgium revises its thin cap rules. Retrieved June 20, 2021, from https://www.dlapiper.com/cs/czech/insights/publications/2012/07/belgiumrevises-its-thin-cap-rules/.

Harju, J., Kauppinen, I. and Ropponen, O. (2017). Firm Responses to an Interest Barrier: Empirical Evidence. Working Papers 90, VATT Institute for Economic Research. International Monetary Fund (2015). IMF: developing countries' BEPS revenue losses exceed $\$ 200$ billion. Retrieved June 15, 2019, from http://uncounted.org/2015/06/01/imfdeveloping-countries-beps-revenue-losses-exceed-200-billion/.

Janský, P. and Kokeš, O. (2015). Corporate tax base erosion and profit shifting out of the Czech Republic. Post-Communist Economies, 27(4), pp. 537-546. Available at https://doi.org/10.1080/14631377.2015.1084733. 
Janský, P. and Kokeš, O. (2016). Profit-shifting from the Czech multinational companies to European tax havens. Applied Economic Letters 1-4. Available at http://dx.doi.org/10. 1080/13504851.2015.1137543.

Mardan, M. (2015). Why Countries Differ in Thin Capitalization Rules: The Role of Financial Development. CESIFO Working Paper No. 5295, Center for Economic Studies \& Ifo Institute, ISSN 2364-1428.

Murphy, R. (2019). The European Tax Gap [online]. Retrieved December 14, 2019, from https://www.socialistsanddemocrats.eu/sites/default/files/2019-01/the_european_tax_gap _en_190123.pdf.

OECD (2016). Limiting Base Erosion Involving Interest Deductions and Other Financial Payments, Action 4 - 2016 Update: Inclusive Framework on BEPS, OECD/G20 Base Erosion and Profit Shifting Project, OECD Publishing, Paris. Available at https://doi.org/ 10.1787/9789264268333-en.

Overesch, M. (2009). The Effects of Multinationals' Profit Shifting Activities on Real Investment. National Tax Journal, 62(1), 5-23.

Pekárek, A. and Pilařová, I. (2016). Nízká kapitalizace [online]. Retrieved February 12, 2019, from https://www.du.cz/33/nizka-kapitalizace-uniqueidmRRWSbk196FNf8-jVUh4EmtBL-kb09JE-YQ1PrJRretZwRYsMFH_3w/.

Pilařová, I. (2012). Daňová uznatelnost úroků z úvěrů a půjček v podmínkách roku 2012. Daně a právo v praxi, 5(12). Retrieved February 12, 2019, from https://www.dauc.cz/dokument $/$ ?modul=li\&cislo=40822.

Pivoňková, A. (2019). Daňová uznatelnost finančních nákladů v České republice. Diploma theses, Prague University of Economics and Business.

PWC (2021). Worldwide Tax Summary: Belgium. Retrieved June 20, 2021, from https://taxsummaries.pwc.com/belgium/corporate/group-taxation.

Sobotková, V. (2010). Komparace vlivu aplikace pravidel nízké kapitalizace na daňové zatîžení poplatníka České republiky s ohledem na legislativní vymezení spojených osob. Acta Universitatis Agriculturae et Silviculturae Mendelianae Brunensis. LVIII, No. 6, pp. 453-464.

Sobotková, V. (2012). Tak trochu jinak o pravidlech nízké kapitalizace. Daně a právo v praxi, 11(12). Retrieved February 13, 2019, from https://www.dauc.cz/dokument/?modul $=$ li\&cislo $=42808 \& \mathrm{rez}=0 \& \mathrm{q}=\mathrm{n} \% \mathrm{C} 3 \% \mathrm{ADzk} \% \mathrm{C} 3 \% \mathrm{~A} 1 \% 20$ kapitalizace.

Tørsløv, R., Thomas, Wier, S., Ludvig and Zucman, G. (2018). The missing profits of nations. Working Paper 24701, NBER Working Paper Series. Available at http://www.nber. org/papers/w24701.

Vicard, V. (2015). Profit Shifting Through Transfer Pricing: Evidence from French Firm Level Trade Data. SSRN Paper No. 2614864. Available at https://doi.org/10.2139/ssrn.2614864. 